\title{
Quantification of nitrotyrosine in nitrated proteins
}

\author{
Hong Yang • Yingyi Zhang • Ulrich Pöschl
}

Received: 17 December 2009/Revised: 6 February 2010 / Accepted: 8 February 2010 /Published online: 19 March 2010

(C) The Author(s) 2010. This article is published with open access at Springerlink.com

\begin{abstract}
For kinetic studies of protein nitration reactions, we have developed a method for the quantification of nitrotyrosine residues in protein molecules by liquid chromatography coupled to a diode array detector of ultraviolet-visible absorption. Nitrated bovine serum albumin (BSA) and nitrated ovalbumin (OVA) were synthesized and used as standards for the determination of the protein nitration degree (ND), which is defined as the average number of nitrotyrosine residues divided by the total number of tyrosine residues in a protein molecule. The obtained calibration curves of the ratio of chromatographic peak areas of absorbance at 357 and at $280 \mathrm{~nm}$ vs. nitration degree are nearly the same for BSA and OVA (relative deviations $<5 \%$ ). They are near-linear at low ND $(<0.1)$ and can be described by a second-order polynomial fit up to $\mathrm{ND}=0.5\left(R^{2}>0.99\right)$. A change of chromatographic column led to changes in absolute peak areas but not in the peak area ratios and related calibration functions, which confirms the robustness of the analytical method. First results of laboratory experiments confirm that the method is applicable for the investigation of the reaction kinetics of protein nitration. The main advantage over alternative methods is that nitration degrees can be efficiently determined without hydrolysis or digestion of the investigated protein molecules.
\end{abstract}

Keywords Nitrotyrosine - HPLC-DAD · BSA · OVA · Nitration degree

H. Yang $(\bowtie) \cdot$ Y. Zhang $\cdot$ U. Pöschl

Biogeochemistry Department, Max Planck Institute for Chemistry, 55128 Mainz, Germany

e-mail: h.yang@mpic.de

\section{Introduction}

The nitration of biomolecules, including proteins, deoxyribonucleic acid (DNA), and lipids, plays an important role in biological systems and human diseases. It can trigger cellular responses ranging from subtle modulations of cell signaling to oxidative injury, committing cells to necrosis or apoptosis $[1,2]$. For example, the reaction between free radicals nitrogen oxide $\left(\mathrm{NO}^{\circ}\right)$ and superoxide $\left(\mathrm{O}_{2}{ }^{--}\right)$under physiological conditions can form strong oxidizing and nitrating intermediates such as peroxynitrite $\left(\mathrm{ONO}_{2}{ }^{-}\right)$, which can nitrate tyrosine residues in proteins [3-6]. Peroxynitrite-mediated damage has been implicated in a wide range of disease pathologies [1,7], and nitrotyrosine has been established as a footprint of nitro-oxidative damage in vivo both in animal models and human diseases and as a biomarker of disease progression and severity in conditions such as acute and chronic inflammatory processes [7].

Franze et al. [8] found that nitration of proteins can also occur upon exposure to nitrogen oxides and ozone in synthetic gas mixtures and polluted urban air (summer smog), and they proposed that protein nitration may be a molecular rationale for the promotion of allergies by trafficrelated air pollution $[9,10]$. This hypothesis was supported by Gruijthuijsen et al. [11], who showed in immunological experiments with cells, mice, and human sera that nitration indeed enhances the allergenic potential of proteins. Thus, further investigations of protein nitration by air pollutants are under way, and suitable analytical techniques are required. In particular, laboratory studies characterizing the reaction kinetics of protein nitration under a wide range of well-defined experimental conditions require efficient ways of quantifying nitrotyrosine in protein molecules.

The detection and quantification methods reported for nitrotyrosine can be generally categorized into the following 
groups: immunochemistry, ultraviolet-visible (UV-Vis) photometry, gas chromatography (GC) coupled to a thermal energy analyzer or mass spectrometer, and high-performance liquid chromatography (HPLC) coupled to UV-Vis absorption, fluorescence, electrochemical, and mass spectrometric detectors [12-14]. Immunochemistry has been applied extensively but is generally regarded as semiquantitative $[7,13,15,16]$. UV-Vis photometry enables the detection of nitrotyrosine as a free amino acid as well as in peptides and proteins. As illustrated in Fig. 1, tyrosine and nitrotyrosine both exhibit an absorption peak at $280 \mathrm{~nm}$, and nitrotyrosine has an additional peak at $\sim 357 \mathrm{~nm}$ in acidic solutions $(\mathrm{pH} \leq 3.5)$ or at $\sim 430 \mathrm{~nm}$ in basic solutions ( $\mathrm{pH} \geq 9.5$ ) [17]. Due to low sensitivity and low specificity, the application of simple photometry is restricted to relatively pure and large amount of substance $[15,16,18]$.

The advantages and disadvantages of various GC and HPLC methods and related sample preparation techniques have been reviewed by Duncan [13] and Herce-Pagliai et al. [12]. In the reported GC and HPLC methods, proteins had to undergo hydrolysis or enzymatic digestion to release nitrotyrosine as a free amino acid, whereby artificial formation or loss of nitrotyrosine are of concern. Methods that account for artificial formation or loss of nitrotyrosine have been developed, but they tend to be highly labor and cost intensive. For example, Yi et al. [19] developed gas phase $\mathrm{HCl}$ hydrolysis followed by liquid chromatographytandem mass spectrometry (LC-MS-MS) analysis using isotopomeric $\left[{ }^{13} \mathrm{C}_{6}\right]$-tyrosine as an internal standard. Walcher et al. [14] characterized nitrated proteins by LCMS-MS analysis of oligopeptides obtained by tryptic digestion, which provides insight into the spatial distribution of nitrotyrosine residues in the protein molecule but is less suitable for efficient quantification.

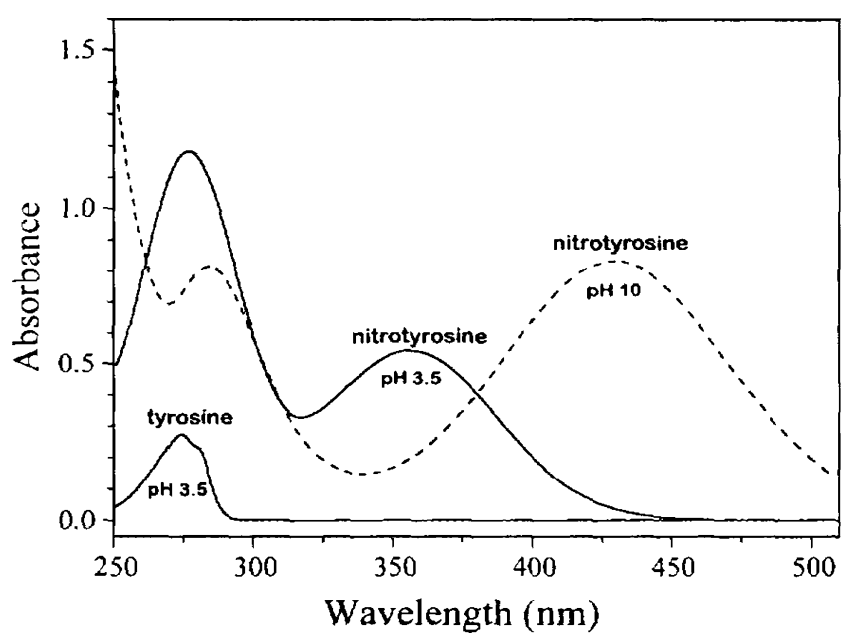

Fig. 1 UV-visible spectra of tyrosine and nitrotyrosine (reprinted from Crow and Beckman [15], with permission from Elsevier)
In this study, we develop and present a simple, inexpensive, and robust HPLC-UV-Vis-DAD method for the determination of the protein nitration degree (ND), which is defined as the average number of nitrotyrosine residues divided by the total number of tyrosine residues in a protein molecule. Our method is based on the one developed by Crow and Beckman [17] for free nitrotyrosine. As demonstrated below, it is applicable for characterizing the reaction kinetics of protein nitration by nitrogen oxides and ozone.

\section{Materials and methods}

\section{Materials}

Bovine serum albumin (BSA; A7638-5G), ovalbumin (Grade V, A5503-5G), tetranitromethane (T25003-5G), phosphate-buffered saline (PBS) tablet (P4417-50TAB), and bicinchoninic acid assay (BCA) kit (BCA1-1KT) were obtained from Sigma-Aldrich, Schnelldorf, Germany. L-3Nitrotyrosine (ALX-106-020-G001) was obtained from Alexis, Grünberg, Germany. Acetonitrile (ACN; ROTISOLV HPLC Gradient Grade) was obtained from Carl Roth $\mathrm{GmbH}+$ Co. KG, Karlsruhe, Germany. Water for chromatography (LiChrosolv) and water with $0.1 \%(v: v)$ trifluoroacetic acid (LiChrosolv) were obtained from Merck KGaA, Darmstadt, Germany. For all other purposes, high-purity water $(18.2 \mathrm{M} \Omega \mathrm{m})$ was taken from an ELGA LabWater system (PURELAB Ultra, ELGA LabWater Global Operations, UK). Synthetic air, nitrogen (99.9995\%), and $\sim 5$ ppmv $\mathrm{NO}_{2}$ in $\mathrm{N}_{2}$ (99.9995\%) were obtained from AIR LIQUIDE Deutschland GmbH, Germany.

Size exclusion chromatography columns PD-10 Sephadex G-25 M (17-0851-01) and PD MiniTrap G-25 (28-9180-08) were obtained from GE Healthcare, Freiburg, Germany. UV microcuvettes (Brand, 612-5688) were obtained from VWR International $\mathrm{GmbH}$, Darmstadt, Germany. Syringe filters (cellulose acetate membrane, $1.2-\mu \mathrm{m}$ pore size, $30-\mathrm{mm}$ diameter, sterile. FP 30) were obtained from Whatman $\mathrm{GmbH}$, Dassel, Germany. Ninety-six-well plates (Product \#9017) were from Corning Incorporated, Corning, NY 14831, USA. Sealing films (SealPlate ${ }^{\circledR}$ ) were from EXCEL Scientific, Inc., Wrightwood, CA 92397, USA.

Preparation of nitrated protein standards

The preparation of nitrated protein standards basically followed the optimized nitration procedure described by Franze et al. [15]. Briefly, the protein was dissolved in PBS $(50 \mathrm{mg} / \mathrm{ml} \mathrm{BSA}$ or $10 \mathrm{mg} / \mathrm{ml} \mathrm{OVA})$. Aliquots of the protein solution $(2.5 \mathrm{ml})$ were pipetted into $20-\mathrm{ml}$ glass vials with screw caps. Tetranitromethane (TNM) dissolved in methanol $(4 \% v / v)$ was added in different amounts corresponding to 
the TNM/tyrosine ratios listed in Table 1. The reaction mixtures were stirred with Teflon-coated magnetic bars at room temperature $\left(\sim 25{ }^{\circ} \mathrm{C}\right)$, and the reaction times were varied in the range of 35-230 min (Table 1). Each reaction mixture was then pipetted onto a PD-10 size exclusion chromatography column and eluted with water. The columns had been prewashed with $40 \mathrm{ml}$ of water, and upon elution of the reaction mixtures the first $2.5 \mathrm{ml}$ of the flow through
Table 1 Nitrated protein standards prepared by reaction of TNM with BSA or OVA in PBS
$\mathrm{TNM} / \mathrm{Tyr}$ is the molar ratio of TNM to tyrosine residues in the reaction mixture; NTN is the number of nitrated tyrosine residues per protein molecule, and $\mathrm{ND}$ is the nitration degree

\begin{tabular}{|c|c|c|c|c|}
\hline Protein standards & TNM/Tyr & Reaction time (min) & NTN & ND \\
\hline \multicolumn{5}{|l|}{ BSA } \\
\hline Nitro-(0.08)-BSA & 0.05 & 120 & 0.08 & 0.004 \\
\hline Nitro-(0.3)-BSA & 0.10 & 120 & 0.34 & 0.016 \\
\hline Nitro-(0.6)-BSA & 0.24 & 35 & 0.57 & 0.027 \\
\hline Nitro-(0.7)-BSA & 0.15 & 120 & 0.71 & 0.034 \\
\hline Nitro-(1.1)-BSA-1 & 0.24 & 140 & 1.1 & 0.051 \\
\hline Nitro-(1.1)-BSA-2 & 0.20 & 120 & 1.1 & 0.052 \\
\hline Nitro-(1.3)-BSA & 0.24 & 120 & 1.3 & 0.060 \\
\hline Nitro-(1.9)-BSA & 0.29 & 120 & 1.9 & 0.090 \\
\hline Nitro-(2.1)-BSA & 0.34 & 120 & 2.1 & 0.098 \\
\hline Nitro-(2.4)-BSA & 0.39 & 120 & 2.4 & 0.114 \\
\hline Nitro-(2.8)-BSA & 0.49 & 70 & 2.8 & 0.133 \\
\hline Nitro-(2.9)-BSA & 0.49 & 140 & 2.9 & 0.138 \\
\hline Nitro-(4.0)-BSA & 0.49 & 140 & 4.0 & 0.189 \\
\hline Nitro-(6.0)-BSA & 1.0 & 140 & 6.0 & 0.284 \\
\hline Nitro-(8.2)-BSA & 3.0 & 170 & 8.2 & 0.389 \\
\hline Nitro-(8.3)-BSA & 3.9 & 200 & 8.3 & 0.394 \\
\hline Nitro-(10.1)-BSA & 7.9 & 230 & 10.1 & 0.482 \\
\hline \multicolumn{5}{|l|}{ OVA } \\
\hline Nitro-(0.2)-OVA & 0.3 & 35 & 0.18 & 0.018 \\
\hline Nitro-(0.3)-OVA-1 & 0.3 & 70 & 0.27 & 0.027 \\
\hline Nitro-(0.3)-OVA-2 & 1.7 & 35 & 0.30 & 0.030 \\
\hline Nitro-(0.5)-OVA & 0.7 & 70 & 0.52 & 0.052 \\
\hline Nitro-(0.6)-OVA & 1.7 & 70 & 0.55 & 0.055 \\
\hline Nitro-(0.8)-OVA & 3.5 & 70 & 0.79 & 0.079 \\
\hline Nitro-(1.2)-OVA & 3.5 & 140 & 1.2 & 0.121 \\
\hline Nitro-(2.3)-OVA & 6.9 & 140 & 2.3 & 0.227 \\
\hline Nitro-(4.1)-OVA-1 & 13.9 & 180 & 4.1 & 0.411 \\
\hline Nitro-(4.1)-OVA-2 & 13.9 & 180 & 4.1 & 0.412 \\
\hline Nitro-(4.1)-OVA-3 & 13.9 & 180 & 4.1 & 0.415 \\
\hline Nitro-(4.2)-OVA-1 & 13.9 & 180 & 4.2 & 0.418 \\
\hline Nitro-(4.2)-OVA-2 & 13.9 & 180 & 4.2 & 0.424 \\
\hline Nitro-(4.3)-OVA-1 & 13.9 & 180 & 4.3 & 0.426 \\
\hline Nitro-(4.3)-OVA-2 & 13.9 & 180 & 4.3 & 0.429 \\
\hline Nitro-(4.3)-OVA-3 & 13.9 & 180 & 4.3 & 0.432 \\
\hline Nitro-(4.3)-OVA-4 & 13.9 & 180 & 4.3 & 0.434 \\
\hline Nitro-(4.4)-OVA-1 & 13.9 & 180 & 4.4 & 0.441 \\
\hline Nitro-(4.4)-OVA-2 & 13.9 & 180 & 4.4 & 0.441 \\
\hline Nitro-(4.4)-OVA-3 & 13.9 & 180 & 4.4 & 0.443 \\
\hline Nitro-(4.4)-OVA-4 & 13.9 & 180 & 4.4 & 0.444 \\
\hline Nitro-(4.5)-OVA-1 & 13.9 & 180 & 4.5 & 0.446 \\
\hline Nitro-(4.5)-OVA-2 & 13.9 & 180 & 4.5 & 0.447 \\
\hline Nitro-(4.5)-OVA-3 & 13.9 & 180 & 4.5 & 0.452 \\
\hline Nitro-(4.6)-OVA & 13.9 & 180 & 4.6 & 0.457 \\
\hline
\end{tabular}


was discarded, and the subsequent $\sim 3.5 \mathrm{ml}$ of the eluate was collected. Two aliquots of the eluate were taken to determine the protein concentration $(50 \mu \mathrm{l})$ and the concentration of nitrotyrosine residues $(150 \mu \mathrm{l})$, respectively. The remaining eluate was dried under a high-purity $\mathrm{N}_{2}$ stream or in a freezedrier (ALPHA 2-4 LDplus, Martin Christ Gefriertrocknungsanlagen $\mathrm{GmbH}$, Germany) and stored in a refrigerator at $\sim 4{ }^{\circ} \mathrm{C}$.

The protein concentration in the eluate was determined with a BCA assay. The $50 \mu 1$ eluate aliquot was diluted with water to $2 \mathrm{ml}$ to a concentration in the range of $200-1,000 \mu \mathrm{g} /$ $\mathrm{ml}$, and $0.1 \mathrm{ml}$ of this diluted solution was then mixed with $2 \mathrm{ml}$ of the BCA working reagent. After incubation at room temperature for 3-6 $\mathrm{h}$, the absorbance of the solution was measured at $562 \mathrm{~nm}$ (UV-Vis Spectrometer, Perkin Elmer, Lambda 25 ) with a statistical uncertainty of $\sim 1.5 \%$ (relative standard deviation of triplicate measurements). The measured protein concentration was used to calculate the total amount of protein in the eluate and subsequently the recovery of protein from the nitration reaction.

The concentration of nitrotyrosine residues in the eluate was determined by dilution of the $150 \mu$ l eluate with $0.05 \mathrm{~N}$ $\mathrm{NaOH}$ into $1.5 \mathrm{ml}$ solution and measurement of absorbance at $425 \mathrm{~nm}$ calibrated against 3-nitrotyrosine in $0.05 \mathrm{~N}$ $\mathrm{NaOH}$ (Perkin Elmer, Lambda 25) with a statistical uncertainty of $\sim 0.4 \%$ (relative standard deviation of triplicate measurements). The nitrotyrosine residue number per protein molecule (NTN) was then determined from the amount of substance (mol) of nitrotyrosine divided by the amount of substance of protein. For the statistical uncertainty of the calculated NTN values, we obtained an estimate of $\sim 1.6 \%$ by propagation of the relative uncertainties of the nitrotyrosine and protein concentration measurements (NIST reference on constants, units, and uncertainty, http://physics. nist.gov/cuu/Uncertainty/index.html). Based on the NTN value, the nitrated protein standards were designated as nitro-(NTN)-BSA or nitro-(NTN)-OVA (Table 1). The ND was calculated by dividing the NTN through the total number of tyrosine residues in a protein molecule ( 21 for BSA and 10 for OVA).

\section{HPLC-DAD system and operation}

The dilute protein solutions applied in the BCA assay were also analyzed with the HPLC-DAD system (Agilent Technologies 1200 Series) consisting of a binary pump (G1312B), a four-channel microvacuum degasser (G1379B), a column thermostat (G1316B), an autosampler with thermostat (G1330B), and a photo-diode array detector (DAD, G1315C). Chemstation software (Version B.03.01, Agilent) was used for system control and data analysis.

A monomerically bonded C18 column (Vydac 238TP, $250 \mathrm{~mm} \times 2.1 \mathrm{~mm}$ i.d., particle size $5 \mu \mathrm{m}$, Grace Vydac,
Alltech) was used for the chromatographic separation. Gradient elution was applied with $0.1 \%(v / v)$ trifluoroacetic acid in water and ACN at the flow rate of $300 \mu 1 / \mathrm{min}$. The chromatographic run started with $0.1 \%(v / v)$ trifluoroacetic acid in water, and then the ACN content was increased to $100 \%$ within $20 \mathrm{~min}$. The mobile phase composition was reset to initial conditions within $10 \mathrm{~min}$, and the column was equilibrated for $2 \mathrm{~min}$ before the next run. The absorbance was monitored with the DAD at 280 and $357 \mathrm{~nm}$. The sample injection volume was $100 \mu$ l. The separation of peaks between native and nitrated proteins was not observed in our analysis. Native and nitrated proteins were eluted out as one peak. The retention time is between 12.5 and $14 \mathrm{~min}$ for native/nitrated BSA and 15 and 16 min for native/nitrated OVA.

Exposure of protein samples to synthetic gas mixtures

Syringe filters were prewashed with autoclaved high-purity water $(18.2 \mathrm{M} \Omega \mathrm{m})$ and freeze-dried. One hundred microliters of BSA aqueous solution $(\sim 5 \mathrm{mg} / \mathrm{ml})$ was pipetted onto the prewashed filter and freeze-dried $(\sim 0.2 \mathrm{mbar}$ for 40 60 min). The BSA-loaded syringe filters were then exposed to a synthetic gas flow containing variable amounts of nitrogen dioxide, ozone, and water vapor. $\mathrm{NO}_{2}$ was supplied from a gas cylinder $\left(\sim 5 \mathrm{ppmv} \mathrm{NO}_{2}\right.$ in $\mathrm{N}_{2} 99.9995 \%$ ) at a flow rate of $10-70 \mathrm{ml} / \mathrm{min}$. Ozone was produced from synthetic air passing through a mercury vapor lamp (Jelight Company, Inc., Irvine, USA) at $\sim 1.5 \mathrm{l} / \mathrm{min}$. At the end of a dark flow tube $(\sim 41)$, inside which $\mathrm{NO}_{2}$ in $\mathrm{N}_{2}$ and $\mathrm{O}_{3}$ in synthetic air have been mixed (residence time $\sim 2.5 \mathrm{~min}$ ), water vapor was introduced by passing an $\mathrm{N}_{2}$ flow at $\sim 1.0 \mathrm{l} / \mathrm{min}$ through a washing bottle filled with autoclaved high-purity water. The relative humidity achieved in the gas mixtures was between $30 \%$ and $50 \%$. The concentrations of the trace gases and water vapor were measured with commercial monitoring systems $\left(\mathrm{NO}_{x}\right.$ analyzer, 42i-TL, Thermo SCIENTIFIC; ozone analyzer, 49i, Thermo SCIENTIFIC; the humidity detector, ALMEMO 2390-3, AHLBORN, Mess und Regelungstechnik GmbH, Germany).

The BSA-loaded syringe filters were exposed to the gas mixtures for 1-7 days and then extracted with water $(6 \mathrm{ml})$. The extract was freeze-dried ( 0.8 mbar for $\sim 24 \mathrm{~h}$ until dry), redissolved in $0.5 \mathrm{ml}$ of water, and pipetted onto a PD MiniTrap G-25 column that had been prewashed with $8 \mathrm{ml}$ of water. The flow through was discarded, and the column was eluted with $1 \mathrm{ml}$ of water. The eluate was collected and used for analysis with HPLC-DAD to determine nitration degree values for the products of the exposure experiments and for determination of protein concentration by $\mathrm{BCA}$ assay to subsequently calculate the protein recovery rate. Because the amount of the sample is small, BCA assay based on 96-well plate was employed. Briefly, three 
portions of $25-\mu 1$ solution were taken for every standard or sample and pipetted into a 96-well plate for triplicate measurements. Two hundred microliters of BCA working reagent was then added. The 96-well plate was sealed with a sealing film; the samples were incubated for 3-6 h at room temperature $\left(\sim 25^{\circ} \mathrm{C}\right)$, and the absorbance of the solutions was measured with MULTISKAN EX (Thermo Electron Corporation) at $560 \mathrm{~nm}$.

\section{Results and discussion}

Characterization of nitrated protein standards

Nitrated protein standards were prepared by reaction of BSA and OVA with TNM at different molar ratios and reaction times, and their ND was determined by UV-Vis photometry as detailed above ("Preparation of nitrated protein standards"). Within the investigated range of experimental conditions (Table 1), the ND values exhibited only a weak dependence on reaction time but a strong dependence on the molar ratio of TNM to tyrosine residues (TNM/Tyr). As illustrated in Fig. 2, with increasing $\mathrm{TNM} / \mathrm{Tyr}$ ratio up to $\sim 14$, the observed increase of ND was near-logarithmic for BSA and near-linear for OVA. The nitration of tyrosine residues within a protein depends on three main factors: the protein structure, the nitration mechanism, and the chemical environment of the protein [20]. As the nitration of both BSA and OVA was carried out in vitro with TNM and the reaction conditions were essentially the same, the different dependencies of ND on the TNM/Tyr ratio for BSA and OVA are likely due to the different protein structures of BSA and OVA.

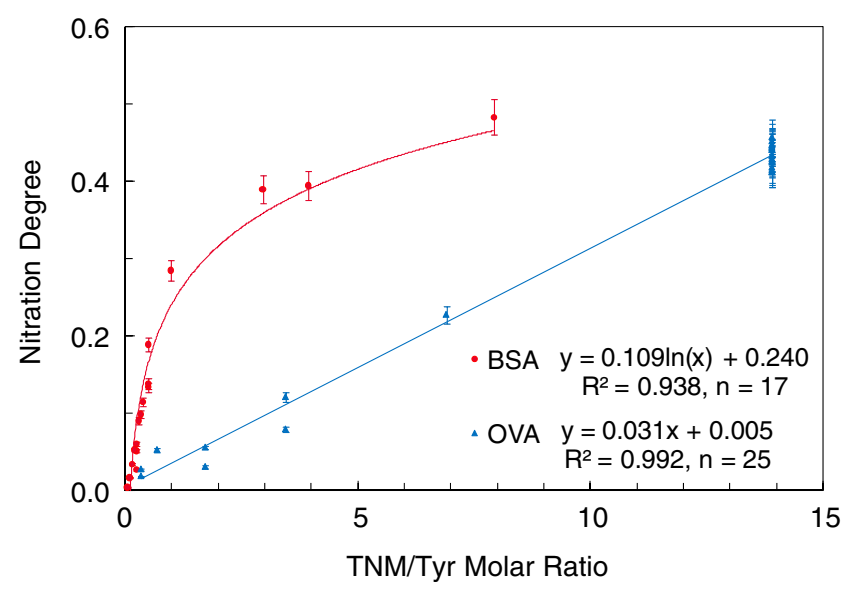

Fig. 2 Nitration degree vs. molar ratio of TNM to tyrosine residues (TNM/Tyr) for nitrated protein standards of bovine serum albumin $(B S A)$ and ovalbumin $(O V A)$ synthesized by reaction with TNM in liquid phase. The error bars represent the statistical uncertainty of the analytical method $( \pm 3 \mathrm{~s})$. They do not include uncertainty due to the variability of reaction conditions. The lines are least-square fits (logarithmic for BSA, linear for OVA)
The average recovery rates of the protein standards after nitration by TNM and cleanup with size exclusion chromatography column were $73.1 \pm 14.3 \%$ for nitrated BSA $(n=17)$ and $94.8 \pm 9.2 \%$ for nitrated OVA $(n=25$; arithmetic mean \pm standard deviation). At higher TNM/Tyr ratios, we observed precipitation of yellowish solids from the reaction mixture, which is likely due to a cross-linking of protein molecules as a result of the reaction of two TyrO radicals [20].

\section{Determination of nitration degrees by HPLC-DAD}

Figure 3 shows the HPLC-DAD calibration curves obtained with the nitrated protein standards. The relations between nitration degree and the ratio of absorbance peak areas at 357 and $280 \mathrm{~nm}\left(\mathrm{~A}_{357} / \mathrm{A}_{280}\right)$ can be described by second-order polynomials $\left(R^{2}>0.99\right)$. At low nitration degrees (ND $<0.2$ ), they are near-identical for BSA and OVA (relative deviations $<2 \%$ ). Even at high nitration degrees (ND 0.5), the relative deviations between the BSA and OVA calibration curves $(\sim 5 \%$ at $\mathrm{ND}=0.5)$ are not much higher than the statistical uncertainty of $\mathrm{A}_{357} / \mathrm{A}_{280}$ ( $\sim 2 \%$ relative standard deviation of nine replicate measurements), suggesting that one single calibration curve can be applied for determining the nitration degrees of different types of nitrated proteins.

At the low nitration degrees that are most relevant for kinetic experiments with nitrating gas mixtures $(\mathrm{ND} \leq 0.1$; "Exemplary application in kinetic experiments"), the calibration curves can be fitted by linear regression $\left(R^{2}>\right.$ 0.99, Fig. 4a).

As illustrated in Fig. 4a, the calibration curve of absorbance peak area ratio $\mathrm{A}_{357} / \mathrm{A}_{280}$ vs. ND remained essentially unchanged when the chromatographic column of the HPLC

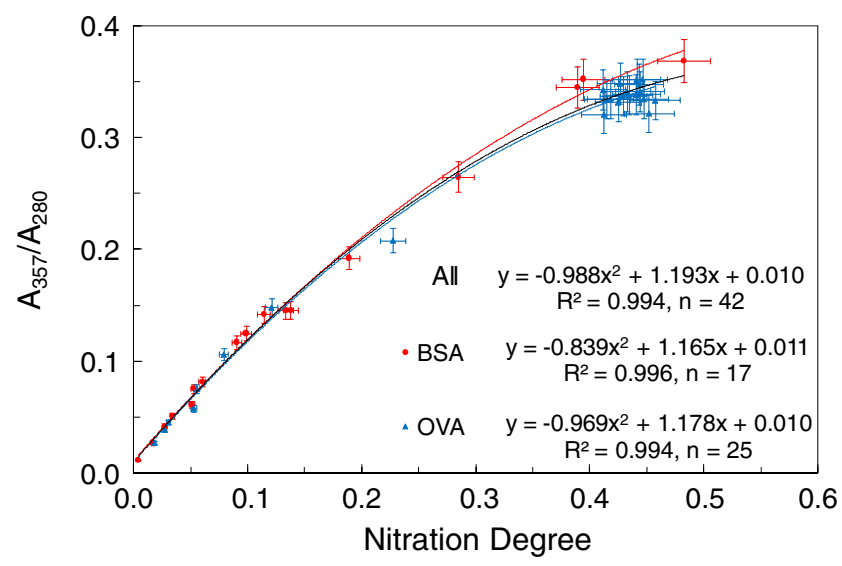

Fig. 3 Calibration curves plotting the ratio of absorbance peak areas at 357 and $280 \mathrm{~nm}\left(\mathrm{~A}_{357} / \mathrm{A}_{280}\right)$ against the nitration degree of nitrated protein standards for BSA (red), OVA (blue), and all samples (dark), respectively. The error bars are relative standard deviations $( \pm 3 \mathrm{~s})$. The solid lines are quadratic least-square fits 


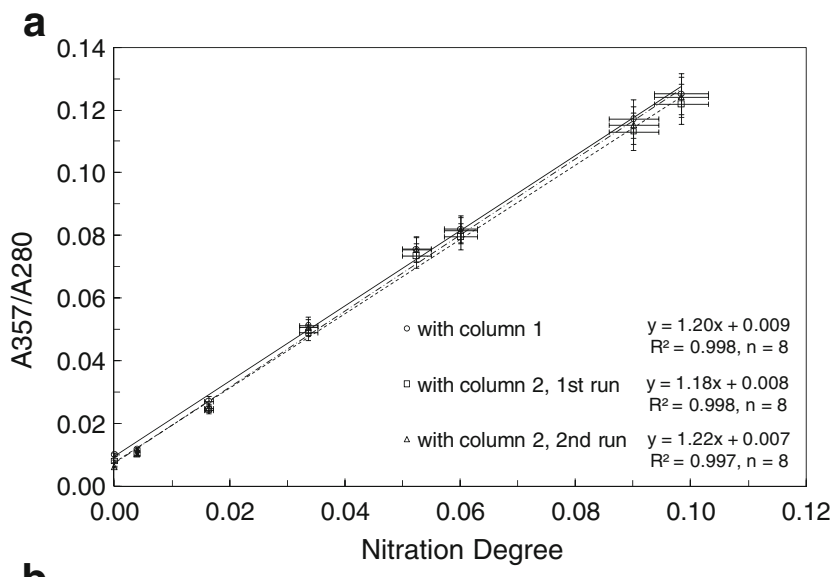

b

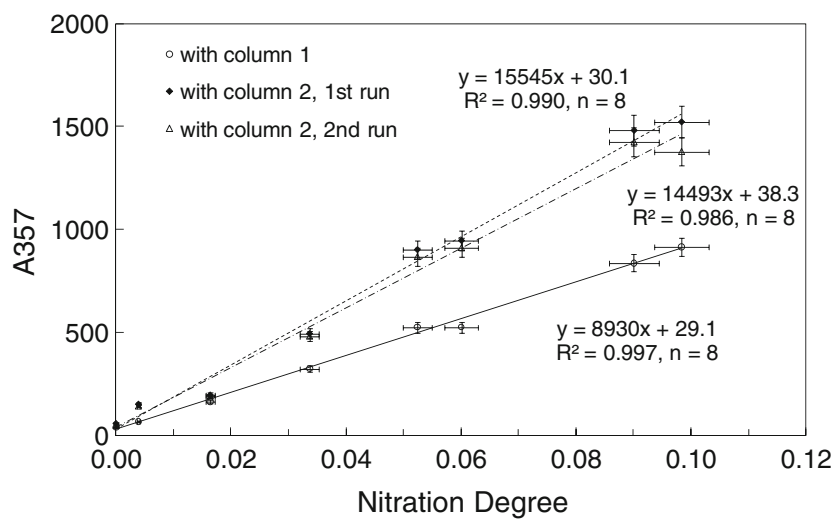

Fig. 4 Calibration lines plotting the ratio of absorbance peak areas at 357 and $280 \mathrm{~nm}\left(\mathrm{~A}_{357} / \mathrm{A}_{280}\right.$, a) or just the absorbance peak area at $357 \mathrm{~nm}\left(\mathrm{~A}_{357}, \mathbf{b}\right)$ against the nitration degree (ND) of nitrated BSA standards measured with different chromatographic columns and at different time. The error bars are relative standard deviations $( \pm 3 \mathrm{~s})$, and the lines are linear least-squares fits

system was exchanged, which demonstrates high robustness of our method. In contrast, an alternative calibration approach using the peak area $\mathrm{A}_{357}$ instead of the peak area ratio $\mathrm{A}_{357} /$ $\mathrm{A}_{280}$ was strongly influenced by the change of chromatographic column (Fig. 4b).

With regard to ND, the detection limit of our method is 0.0005 based on the standard deviation of nine consecutive replicate measurements with unnitrated BSA (3-s method). This corresponds to a concentration of $0.054 \mathrm{pmol} / \mu \mathrm{l}$ of nitrotyrosine residues in the investigated protein solution samples $(4.3 \mathrm{pmol}$ in $80 \mu \mathrm{l})$, which is comparable to the detection limit of 16 pmol nitrotyrosine per $80-\mu 1$ injection volume reported by Crow and Beckmann for free nitrotyrosine [15]. The statistical uncertainty of the ND values determined by our method is $2.5 \%$ (relative standard deviation of nine replicate measurements).

Exemplary application in kinetic experiments

Exemplary applications of the analytical method in our kinetic studies of protein nitration are illustrated in Figs. 5

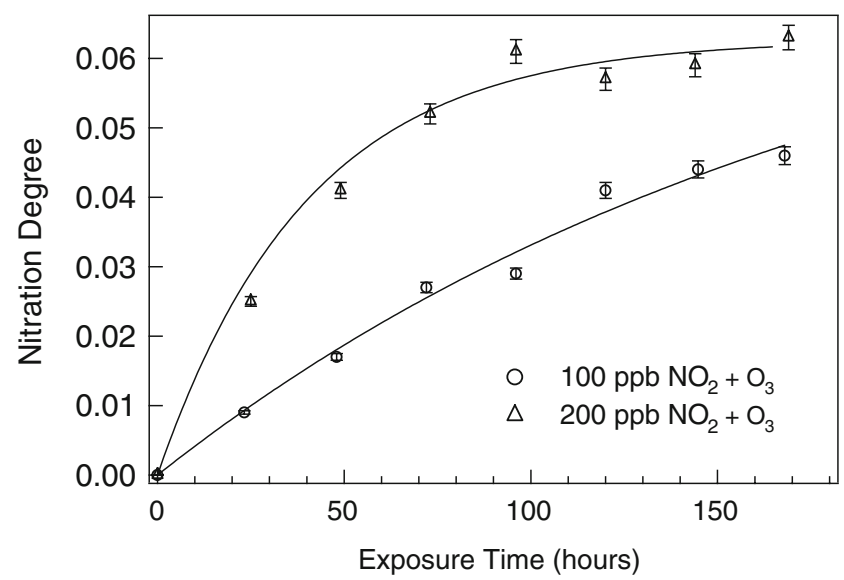

Fig. 5 Nitration degrees plotted against exposure time for BSA exposed to synthetic gas mixtures of $\mathrm{NO}_{2}$ and $\mathrm{O}_{3}$ at $\sim 40 \%$ relative humidity. The error bars represent the statistical uncertainty of the analytical method $( \pm 3 \mathrm{~s})$. They do not include uncertainty due to the variability of reaction conditions. The lines are least-square fits with a pseudo-first-order kinetic rate equation $\mathrm{ND}=\mathrm{ND}_{\max }\left(1-\mathrm{e}^{-k t}\right)$ as discussed in the text

and 6. Figure 5 shows two series of experiments in which BSA was exposed to synthetic gas mixtures of $\mathrm{NO}_{2}$ and $\mathrm{O}_{3}$ for 1-7 days. In one series, protein samples were exposed to $102 \pm 1.9 \mathrm{ppb} \mathrm{NO}_{2}$ and $110 \pm 3.5 \mathrm{ppb} \mathrm{O}_{3}$; in the other series, they were exposed to $212 \pm 8.5 \mathrm{ppb} \mathrm{NO}_{2}$ and $209 \pm$ $5.7 \mathrm{ppb} \mathrm{O}_{3}$ (arithmetic mean \pm standard deviation). The relative humidities in the two experiments were $41 \pm 0.8 \%$ and $37 \pm 0.4 \%$, respectively (arithmetic mean \pm standard devia-

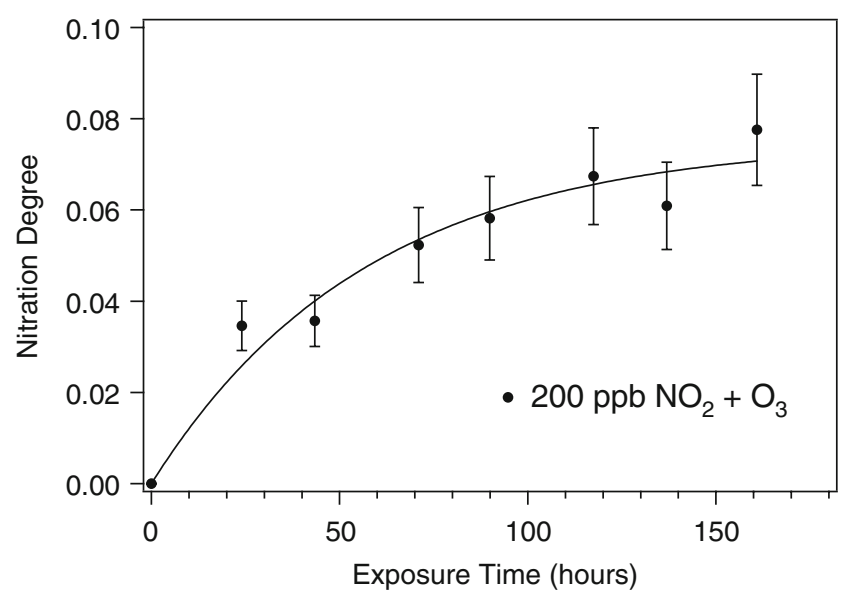

Fig. 6 Nitration degrees plotted against exposure time for OVA exposed to synthetic gas mixtures of $\mathrm{NO}_{2}$ and $\mathrm{O}_{3}$ at $\sim 40 \%$ relative humidity. The error bars represent the statistical uncertainty of the analytical method $( \pm 3 \mathrm{~s})$. They do not include uncertainty due to the variability of reaction conditions. The analytical uncertainties for OVA are higher compared to BSA in this case because the solubility of OVA decreased significantly after being exposed to the gases and thus caused extra uncertainties during the analysis by LC-DAD. The solid line is a least-square fit with a pseudo-first-order kinetic rate equation $\mathrm{ND}=\mathrm{ND}_{\max }\left(1-e^{-k t}\right)$ as discussed in the text 
tion). The exposures were carried out at room temperature ( $\sim 22$ and $\sim 21^{\circ} \mathrm{C}$, respectively).

At $\sim 100 \mathrm{ppb} \mathrm{NO}_{2}+\mathrm{O}_{3}$, the ND of BSA was $\sim 0.01$ after 1 day of exposure and continued to increase steadily up to $\sim 0.04$ after 5 days. At $\sim 200$ ppb $\mathrm{NO}_{2}+\mathrm{O}_{3}$, the $\mathrm{ND}$ was $\sim 0.025$ after 1 day and reached a nearly constant plateau level of $\sim 0.055$ after 4 days. Both curves can be fitted with a pseudo-first-order kinetic rate equation $\mathrm{ND}=\mathrm{ND}_{\max }$ $\left(1-\mathrm{e}^{-k t}\right)$, where $\mathrm{ND}_{\max }$ is the maximum nitration degree, $k$ is a pseudo-first-order rate coefficient, and $t$ stands for reaction time. The fitted pseudo-first-order rate coefficient $k$ is $0.0053 \pm 0.0039 \mathrm{~h}^{-1}$ (coefficient values $\pm 95 \%$ confidence interval) at $\sim 100 \mathrm{ppb} \mathrm{NO}_{2}+\mathrm{O}_{3}$ and $0.0249 \pm 0.0061 \mathrm{~h}^{-1}$ at $\sim 200 \mathrm{ppb} \mathrm{NO}_{2}+\mathrm{O}_{3}$. The maximum nitration degree achieved upon exposure of BSA to $\mathrm{NO}_{2}$ and $\mathrm{O}_{3}(\sim 0.055)$ is by an order of magnitude lower than upon nitration with TNM in aqueous solution $(\sim 0.5)$. The differences can be attributed to the different reactants, conditions, and mechanisms [18], which will be further investigated in follow-up studies.

Figure 6 shows a series of experiments in which OVA was exposed to synthetic gas mixtures of $\mathrm{NO}_{2}$ and $\mathrm{O}_{3}$ for 1-7 days. In this experiment, protein samples were exposed to $208 \pm 0.9 \mathrm{ppb} \mathrm{NO}_{2}$ and $207 \pm 4.3 \mathrm{ppb} \mathrm{O}_{3}$ (arithmetic mean \pm standard deviation). The relative humidity in the experiment was $41 \pm 0.3 \%$ (arithmetic mean \pm standard deviation). The exposures were carried out at room temperature $\left(\sim 22{ }^{\circ} \mathrm{C}\right)$.

At $\sim 200 \mathrm{ppb} \mathrm{NO}_{2}+\mathrm{O}_{3}$, the ND of OVA was $\sim 0.03$ after 1 day of exposure and continued to increase steadily up to $\sim 0.07$ after 5 days. A curve was also fitted with the same pseudo-first-order kinetic rate equation as for BSA. The fitted pseudo-first-order rate coefficient $k$ is $0.0175 \pm$ $0.0103 \mathrm{~h}^{-1}$ (coefficient values $\pm 95 \%$ confidence interval) at $200 \mathrm{ppb} \mathrm{NO}_{2}+\mathrm{O}_{3}$. The maximum nitration degree achieved upon exposure of OVA to $\mathrm{NO}_{2}$ and $\mathrm{O}_{3}(\sim 200 \mathrm{ppb})$ is $\sim 25 \%$ higher than that of BSA. Recovery of OVA after the exposure experiments is lower compared to BSA at the same $\mathrm{NO}_{2}+\mathrm{O}_{3}$ concentration, likely due to cross-linking of OVA molecules during exposure to the gases. The higher $\mathrm{ND}$ and lower recovery seem to indicate that OVA is more reactive to $\mathrm{NO}_{2}+\mathrm{O}_{3}$ than $\mathrm{BSA}$.

At this point, the exemplary applications illustrate that the developed analytical method is suitable for efficient determination of the nitration degree of the products formed upon exposure of proteins to gaseous nitrating agents.

\section{Conclusions}

Nitrated protein standards of BSA and OVA were synthesized by reaction with TNM in liquid phase. The NDs of the protein standards were determined by UV-Vis photometry and exhibited a pronounced dependence on the TNM/tyrosine molar ratio. For BSA, the dependence was steeper and nearlogarithmic, for OVA, it was less steep and near-linear. The differences in reactivity are likely due to the different molecular structures of the proteins. The standards were used to develop an HPLC-DAD method for direct determination of the nitration degree of proteins. The calibration curves of $\mathrm{A}_{357} / \mathrm{A}_{280}$ vs. ND were nearly the same for nitrated BSA and OVA and did not change upon exchange of the chromatographic column. The applicability of the analytical method for kinetic investigations of protein nitration was demonstrated by exemplary experiments in which BSA or OVA was exposed to synthetic gas mixtures of $\mathrm{NO}_{2}, \mathrm{O}_{3}$, and water vapor. The increase of ND observed upon gas exposure could be described by a pseudofirst-order rate equation. The maximum values of ND ( $\sim 0.055$ and 0.07 for BSA and OVA, respectively) were by an order of magnitude lower than upon nitration with TNM $(\sim 0.5)$, which can be attributed to the different reactants, conditions, and mechanisms.

Acknowledgements This study has been funded by the Max Planck Society (MPG). YZ is supported by International Max Planck Research School for Atmospheric Chemistry and Physics. The authors gratefully acknowledge support by M. O. Andreae and W. Elbert.

Open Access This article is distributed under the terms of the Creative Commons Attribution Noncommercial License which permits any noncommercial use, distribution, and reproduction in any medium, provided the original author(s) and source are credited.

\section{References}

1. Pacher P, Beckman JS, Liaudet L (2007) Physiol Rev 87:315424

2. Halliwell B, Whiteman M (2004) Br J Pharmacol 142:231-255

3. Beckman JS, Beckman TW, Chen J, Marshall PA, Freeman BA (1990) Proc Natl Acad Sci U S A 87:1620-1624

4. Beckman JS, Ischiropoulos H, Zhu L, Vanderwoerd M, Smith C, Chen J, Harrison J, Martin JC, Tsai M (1992) Arch Biochem Biophys 298:438-445

5. Beckmann JS, Ye YZ, Anderson PG, Chen J, Accavitti MA, Tarpey MM, White CR, Beckman JS (1994) Biol Chem Hoppe Seyler 375:81-88

6. Ischiropoulos H, Zhu L, Chen J, Tsai M, Martin JC, Smith CD, Beckman JS (1992) Arch Biochem Biophys 298:431-437

7. Greenacre SAB, Ischiropoulos H (2001) Free Radic Res 34:541-581

8. Franze T, Weller MG, Niessner R, Poschl U (2005) Environ Sci Technol 39:1673-1678

9. Pöschl U (2005) Angew Chem Int Edit 44:7520-7540

10. Traidl-Hoffmann C, Thilo J, Heidrun B (2009) J Allergy Clin Immun 123:558-566

11. Gruijthuijsen YK, Grieshuber I, Stoecklinger A, Tischler U, Fehrenbach T, Weller MG, Vogel L, Vieths S, Poschl U, Duschl A (2006) Int Arch Allergy Immunol 141:265-275. doi:10.1159/ 000095296

12. Herce-Pagliai C, Kotecha S, Shuker DEG (1998) Nitric Oxide 2:324-336 
13. Duncan MW (2003) Amino Acids 25:351-361

14. Walcher W, Franze T, Weller MG, Poschl U, Huber CG (2003) J Proteome Res 2:534-542

15. Franze T, Weller MG, Niessner R, Pöschl U (2003) Analyst 128:824-831

16. Franze T, Weller MG, Niessner R, Poschl U (2004) Analyst 129:589-596
17. Crow JP, Beckman JS (1995) Methods (Orlando) 7:116-120

18. Crow JP, Ischiropoulos H (1996) Nitric oxide, Pt B. Academic, San Diego, pp 185-194

19. Yi D, Ingelse BA, Duncan MW, Smythe GA (2000) J Am Soc Mass Spectrom 11:578-586

20. Bartesaghi S, Ferrer-Sueta G, Peluffo G, Valez V, Zhang H, Kalyanaraman B, Radi R (2007) Amino Acids 32:501-515 